\section{Microsurgical Resection of Supratentorial Cerebral Cavernomas}

\section{Supratentorial Yerleșimli Kavernomların Mikroșirürjikal Rezeksiyonu}

\begin{abstract}
AIM: More than two thirds of cerebral cavernomas are located supratentorially. The transsulcal approach without excision of the perilesional gliotic parenchyma and simple lesionectomy are keys to surgery on eloquent areas.

MATERIAL and METHODS: We present 11 supratentorial cerebral cavernomas operated between 2003 and 2007 with signs of seizures in six and focal neurological deficit in four cases. The age ranged from 19 years to 69 years with a mean of 40 years and the male/female ratio was 6:5. The mean follow-up was 26 months.

RESULTS: All lesions were lobar and the size ranged between 18 and $48 \mathrm{~mm}$. Four were located in eloquent areas and two were deeply seated. Total lesionectomy was performed in all without major complications. A gliotic hemosiderin ring was noted in 7 and resected in 5 of them. Postoperative outcome was improved in all patients with complete seizure control in four. Seizure control was partial in 2 of the cases without any recurrence or residual mass.

CONCLUSION: Asymptomatic cerebral cavernomas should be followed with regular MR scans. Symptomatic ones in noneloquent or accessible areas should be resected. Deeply situated cavernomas in eloquent areas should also be resected with the guidance of fMRI and stereotactic marking if available.
\end{abstract}

KEYWORDS: Cavernous malformation, Microsurgery, Seizure, Cavernoma, Supratentorial, Cerebral

\section{ÖZ}

AMAÇ: Serebral kavernöz malformasyonların üçte ikiden fazlası supratentoryal yerleşimlidir. Perilezyonel gliotik parankimin eksize edilmeden uygulanacak transsulkal yaklaşım ve basit lezyonektomi özellikle değerli kortikal alanlardaki cerrahide anahtar noktadır.

YÖNTEM ve GEREÇ: Bu çalıșmada 2003 ile 2007 yılları arasında nöbet ile başvuran 6 ve fokal nörolojik bulgular ile başvuran 4 olgu olmak üzere 11 supratentoryal serebral kavernomlu olgu incelenmektedir. Olguların yaşları 19 ve 69 arasında değişmekte, ortalama yaş 40 olup, E/K oranı 6.5 olarak tespit edilmiştir. Ortalama takip süresi 26 aydir.

BULGULAR: Tüm lezyonlar lobar yerleşimli olup boyutları 18 ile $48 \mathrm{~mm}$ arasında değişmektedir. Dört olguda kavernom değerli kortikal alanda ve iki olguda ise derin kortikal yerleşimlidir. Total lezyonektomi tüm olgularda herhangi bir major komplikasyon gelişmeden gerçekleştirilmiştir. Gliotik bir hemosiderin halkası 7 hastada görülmüş ve 5 hastada rezeke edilmiştir. Postoperatif dönemde tüm hastalarda iyileşme gözlenmiş ve dört olguda tam nöbet kontrolü sağlanmıştır. İki hastada nöbet ise kontrolü herhangi bir rekürens veya rezidüel kitle etkisi görülmeden parsiyel olmuştur.

SONUÇ: Asemptomatik serebral kavernomlar düzenli MR görüntülemeleri ile takip edilmelidir ancak kortikal değerli olmayan veya ulaşılması kolay bölgelerdeki lezyonlar eksize edilmelidir. Değerli alanlardaki derin yerleşimli kavernomlar da eksize edilmelidir ancak eğer mümkünse bu girişim stereotaktik işaretleme veya fonksiyonel MR ile birlikte uygulanmalıdır.

ANAHTAR SÖZCÜKLER: Kavernöz malformasyon, Mikroşirürji, Nöbet, Kavernom, Supratentoryal serebral, Serebral

\section{Ergun DAGLIOGLU}

Fikret ERGUNGOR

Ersin POLAT

Osman NACAR

Ankara Numune Education and Research Hospital, Department of Neurosurgery,

Ankara, Turkey

Received : 07.06.2008

Accepted : 15.12.2009

Correspondence address: Ergün DAGLIOGLU Kuzgun Sokak, No: 15/14, Aşağı Ayrancı 06540 Ankara, TURKEY Phone : +90 5052296838

Fax : +903123111131

E-mail : edaglioglu@gmail.com 


\section{INTRODUCTION}

Cavernous malformations (CMs) are angiographically occult venous malformations that are considered to be low-flow and wellcircumscribed sinusoid lesions. The prevalence of central nervous system cavernomas ranges between 0.02 and $0.5 \%$ in the population and they make up 5 to $13 \%$ of all cerebrovascular malformations. The majority of CMs present between the 3rd and 5th decades of life (15). Typical histological features are vascular sinusoids lined by endothelium without tight junctions embedded in a collagen matrix without intervening brain parenchyma. Headache, seizures, mass effect and hemorrhage are the most common presentations of CMs. However, the majority of the cases are asymptomatic or have obscure symptoms like mild headache $(18,23)$. Although many cases are found incidentally, the clinical presentation is quite variable in symptomatic cases. Surgical intervention with or without excision of the cortical epileptic focus is considered to be the best treatment for $\mathrm{CMs}$ with intractable seizures. Surgical treatment of CMs has been proposed not only to prevent and/or treat epilepsy but also to diminish the risk and danger of bleeding $(8,19)$. We present the clinical details and outcome of 11 patients operated for supratentorial cerebral CMs.

\section{MATERIAL and METHODS}

\section{Patient Population}

This article presents a retrospective analysis of 11 patients who underwent surgery for symptomatic supratentorial cerebral CMs at Ankara Numune Education and Research Hospital between January 2003 and September 2007.

\section{Neuroimaging Studies}

A 1.5-tesla MR imaging unit was used in all patients whereas cerebral digital subtraction angiography was performed for identification of associated vascular anomalies in 4 patients with hemorrhage or lesions located in deep areas. Postoperative CT scans were performed routinely for every patient.

\section{Surgical Procedures}

The surgical approach was transsulcal in all cavernomas. No intraoperative neuronavigational system or intraoperative neurophysiological mapping was performed during the surgical procedure.

\section{RESULTS}

The age of the patients ranged from 19 years to 69 years with a mean age of 40 years and the male/female ratio was 6:5. The mean follow-up duration was 26 months (range 13-36 months).

All patients had single cavernomas. No patient had a positive familial history for cerebral CMs. The size of the cavernomas ranged from 18 to $48 \mathrm{~mm}$ (mean $29 \mathrm{~mm}$ ). All of the cavernomas were lobar (subcortical and deep white matter), with 4 of 11 lesions located in eloquent areas. Two of 11 cerebral CMs were deeply seated close to basal ganglia. Two of them were located at the temporal lobe (Figure $2 \mathrm{~A}, \mathrm{~B}, \mathrm{C}, \mathrm{D}), 4$ were at the parietal region and 5 were at the frontal region (Figure 1A,B,C,D).

The main clinical presentation included seizures (experienced in 6 cases), focal neurological deficits (4 cases), and chronic headaches (2 cases). Clinical symptoms related to hemorrhage were acute or subacute in 2 cases and chronic in 6. Seizures, which were present in 6 of the patients, were of the generalized tonic clonic and generalized tonic clonic with focal onset type. The epilepsy history was less than 1 year in all cases.

Total lesionectomy was performed in all patients at a single stage operation without major complications. A gliotic hemosiderin ring was noted in 7 of the patients and resected in 5 of the cases with noneloquent cortical localization. No surgery-related death was noted in the present series and the neurological condition improved in 4 of the cases. There was no postoperative deterioration but two patients experienced postoperative asymptomatic minor hemorrhages without any mass effect that resolved 3 weeks after the operation (Figure 3A,B,C,D). At follow-up examination, seizure control was achieved completely in 4 and partially in 2 of the cases without any recurrence or residual mass.

\section{DISCUSSION}

Surgical excision should be considered as the best modality of treatment for symptomatic and superficial lesions, particularly those located in noneloquent areas (27). Both rebleeding and seizure rates were less frequent with craniotomy as compared to radiosurgery although many neurosurgeons hesitate to operate on deeply situated asymptomatic $\mathrm{CM}$ or those with multiple locations 


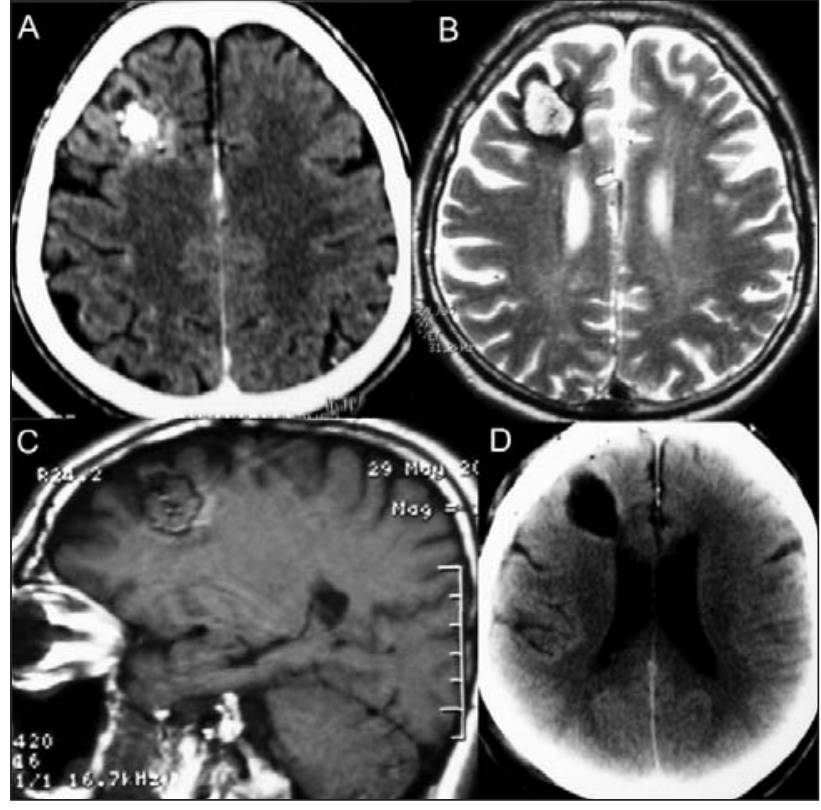

Figure 1: (A) Axial CT scans without contrast demonstrate a right frontal hyperdense lesion, (B) Axial T2-weighted MRI showing the same lesion with typical perilesional hypointense rim, (C) Sagittal T1-weighted image of the same lesion with hypointense rim, (D) Postoperative CT scan revealing complete removal of the cavernoma.

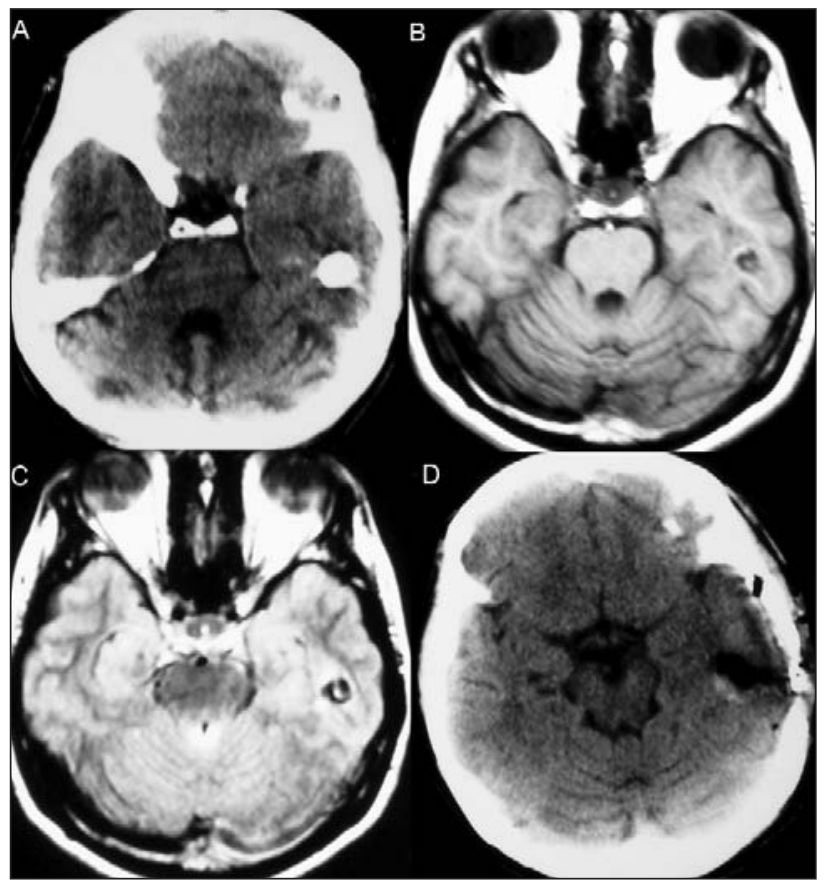

Figure 2: (A) Axial CT scans without contrast demonstrate a left temporal calcified hyperdense lesion, (B) Axial T1-weighted $M R I$ without contrast demonstrate a hypointense central component of the temporal lesion, (C) Axial T2-weighted flair image shows hypointensity on left temporal lobe, (D) Postoperative early CT scan revealing complete removal of the cavernoma.

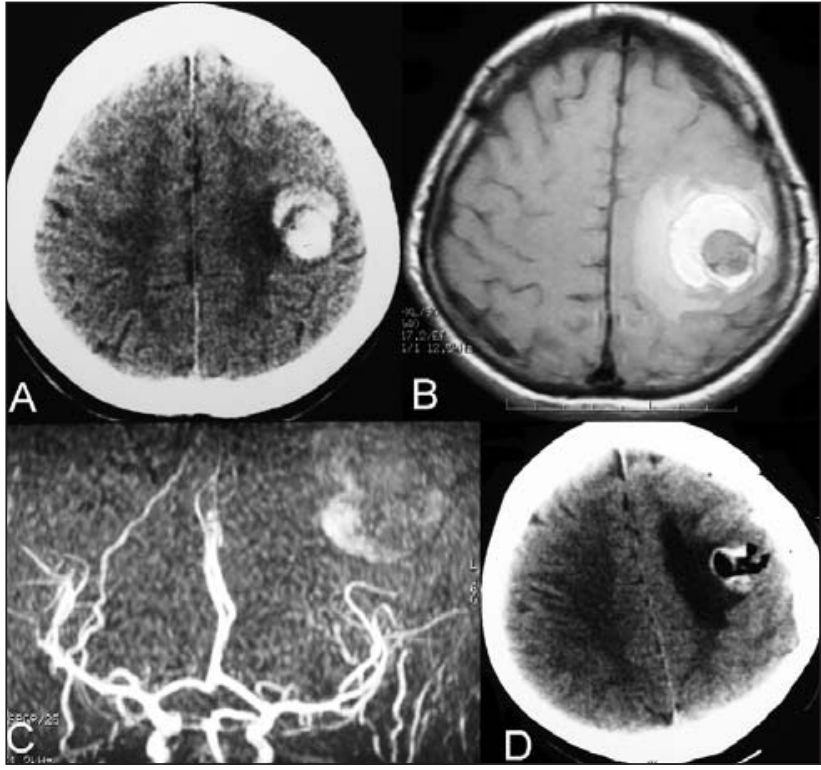

Figure 3: (A) Axial CT scans demonstrate left parietal hyperdense lesion with blood density, (B) Axial T1-weighted $M R I$ without contrast demonstrate a typical double hemorrhage ring typical for cavernoma, (C) MR angiography revealed avascular Axial T2-weighted flair image shows hypointensity on left temporal lobe, (D) Postoperative early CT scan revealing complete removal of the cavernoma.

(4-6). Meanwhile, the moderate efficacy of radiosurgery in arteriovenous malformations has encouraged radiosurgeons to use LINAC or GK as an alternative method of treatment for CMs since $1987(17,18)$. The annual risk of hemorrhage drops significantly with radiosurgery, especially after the first two years of treatment $(17,33)$. In this report, we present $11 \mathrm{CMs}$ with complete removal, four in eloquent areas without any preoperative or postoperative radiation treatment. We propose radical surgical resection for symptomatic cavernomas in eloquent and noneloquent areas.

Gaps between the endothelium processes predispose to leakage through the basal lamina or the defective blood-brain barrier and this leakage to the peripheral brain parenchyma constitutes the main pathophysiological mechanism for bleeding of CMs (7). Furthermore, radiation therapy, hormonal alterations or infectious processes could predispose to overt bleeding of CMs $(11,13,24)$. The defect in the blood-brain barrier also gives clues about the origin of seizures in CMs: not only the mass effect but also the electrical susceptibility of the perilesional parenchyma is important in the etiology of seizures. Ischemia, venous hypertension, gliosis, 
and deposits of blood breakdown products in the adjacent parenchyma may also predispose to seizures in CMs (1). Hemosiderin, hemin or the ionic form of iron may be responsible for epileptogenicity of the perilesional parenchyma (12). Alternatively, another cause of this CM associated epileptogenicity is thought to be due to chronic and clinically silent microhemorrhages $(26,31)$. In general, gliotic hemosiderin-stained brain tissue adjacent to the lesions is thought to be the main source of epileptogenic activity.

About two thirds of patients with cavernomas are seizure-free after microsurgical removal $(2,4,12,20)$. Pure lesionectomy prevents bleeding risk and epilepsy in patients with CMs. This seems to be a logical strategy since this type of removal is less risky with an acceptable rate of morbidity. However, it has been proven that lesion excision alone may not always suffice for seizure control, especially in patients with intractable epilepsy. There remains a group of patients who have persistent seizures postoperatively. If simple lesionectomy is performed without resection of mesial structures in patients with temporal lesions and intractable epilepsy, the seizure control rate is low and ranges from $20 \%$ to $45 \%$ (16). This rate is higher $(60 \%$ to $95 \%)$ for extratemporal localizations (2). Further clinical studies should be planned to detect the perilesional epiloptogenic cerebral cortex if simple lesionectomy fails to cease seizures. Nevertheless, removing perilesional epileptogenic parenchymal tissue is characterized with increased morbidity rates, particularly in eloquent areas $(28,29)$. Excision of the lesion should be accompanied with resection of the gliotic hemosiderin-stained brain parenchyma surrounding the lesion if feasible (noneloquent brain regions) in order to increase the rate of seizure control $(3,10,28)$. Intraoperative electrocorticography can be performed in selected cases to delineate the extent of the cortical epileptogenic zone. However, residual spikes in adjacent brain areas do not reliably predict residual epileptogenicity, nor does their absence guarantee postoperative seizure control (1).

Surgery is less commonly considered for seizure control in patients with a first seizure if associated with a known or newly diagnosed CM. Lesion excision could be performed to prevent bleeding or for solitary accessible lesions in noneloquent areas. It is very important to take into account the exact localization of the $\mathrm{CM}$ and the feasibility of the procedure. Enhanced seizure control or discontinuation of antiepileptic medication cannot be guaranteed without weighing the risks and potential benefits of neurosurgical intervention. One should not hesitate to recommend surgery for symptomatic supratentorial cerebral CMs that are not located superficially or in eloquent areas. However, there is debate about the management of cerebral CMs that are asymptomatic and/or located in eloquent or deep areas $(9,20,30)$. Furthermore, deeply situated lesions or lesions at eloquent areas can be resected with an acceptable risk/benefit ratio if the supplementary clinical tools like stereotactic guidance, electrophysiological monitoring, and/or neuronavigation are used $(20,21,25)$. In the present series, 6 patients presented with seizures and 2 of these had lesions situated at the temporal lobe. Neither the size nor the radiological characteristics of the lesion is correlated with the intensity and frequency of seizures.

Cavernomas are usually hyperdense on CT scans. Widespread use of MR imaging has greatly increased the prevalence of $\mathrm{CMs}$, in particular the ratio of asymptomatic cases. On MR images, they may appear hyper- to isointense on T1-weighted and mixed (with rings of low intensity) on T2-weighted images with a characteristic hypointense ring (Figure $1 \mathrm{~A}, \mathrm{~B}, \mathrm{C}, \mathrm{D})(14,22,32)$. MR imaging is a diagnostic tool as it has high sensitivity and specificity in detecting the hemoglobin degradation products present inside and around the CM. Nevertheless, the diagnosis can be much easier in cases with calcified lesions and a hemosiderin ring as presented on Figure 2A,B,C,D.

\section{CONCLUSION}

Asymptomatic cerebral CMs near eloquent areas should be followed-up with periodic MR images while symptomatic ones in noneloquent or accessible areas should be resected. Deeply situated $\mathrm{CMs}$ or lesions in eloquent areas should also be resected with the guidance of fMRI and stereotactic marking if possible. In cases of cerebral CMs presenting with seizure, studies for electroencephalographic mapping should be performed particularly in those cases where lesionectomy fails. Long-term follow-up is necessary to detect recurrences or de novo lesions. 


\section{REFERENCES}

1. Awad I, Jabbour P: Cerebral cavernous malformations and epilepsy. Neurosurg Focus 21:e7, 2006

2. Awad, IA, Rosenfeld J, Ahl J, Hahn JF, Lüders H: Intractable epilepsy and structural lesions of the brain. Epilepsia 32:179186, 1991

3. Awad IA, Robinson JR: Comparison of the clinical presentation of symptomatic arteriovenous malformations (angiographically visualized) and occult vascular malformations. Neurosurgery 32:876-878, 1993

4. Bertalanffy H, Benes L, Miyazawa T, Alberti O, Siegel AM, Sure U: Cerebral cavernomas in the adult. Review of the literature and analysis of 72 surgically treated patients. Neurosurg Rev 25:1-55, 2002

5. Bertalanffy H, Gilsbach JM, Eggert HR, Seeger W: Microsurgery of deep-seated cavernous angiomas: Report of 26 cases. Acta Neurochir (Wien) 108:91-99, 1991

6. Chen $\mathrm{CL}$, Leu $\mathrm{CH}$, Jan $\mathrm{YJ}$, Shen $\mathrm{CC}$ : Intraventricular cavernous hemangioma at the foramen of Monro: Case report and literature review. Clin Neurol Neurosurg 108:604-609, 2006

7. Clatterbuck RE, Eberhart CG, Crain BJ, Rigamonti D: Ultrastructural and immunocytochemical evidence that an incompetent blood-brain barrier is related to the pathophysiology of cavernous malformations. J Neurol Neurosurg Psychiatry 71:188-192, 2001

8. Cohen DS, Zubay GP, Goodman RR: Seizure outcome after lesionectomy for cavernous malformations. J Neurosurg 83:237-242, 1995

9. D'Angelo VA, De Bonis C, Amoroso R, Cali A, D'Agruma L, Guarnieri V, Muscarella LA, Zelante L, Bisceglia M, Scarabino T, Catapano D: Supratentorial cerebral cavernous malformations: Clinical, surgical, and genetic involvement. Neurosurg Focus 21:e9, 2006

10. Del Curling O Jr, Kelly DL Jr, Elster AD, Craven TE: An analysis of the natural history of cavernous angiomas. J Neurosurg 75:702-708, 1991

11. Fender LJ, Lenthall RK, Jaspan T: De novo development of presumed cavernomas following resolution of E. coli subdural empyemas. Neuroradiology 42:778-780, 2000

12. Ferroli P, Casazza M, Marras C, Mendola C, Franzini A, Broggi G: Cerebral cavernomas and seizures: A retrospective study on 163 patients who underwent pure lesionectomy. Neurol Sci 26:390-394, 2006

13. Gazzaz M, Sichez J, Capelle L, Fohanno D: Recurrent bleeding of thalamic cavernous angioma under hormonal treatment. A case report. (Fr) Neurochirurgie 45:413-416, 1999

14. Gomori JM, Grossman RI, Goldberg HI, Hackney DB, Zimmerman RA, Bilaniuk LT: Occult cerebral vascular malformations: High-field MR imaging. Radiology 158:707713, 1986

15. Hsu FPK, Rigamonti D, Huhn SL: Epidemiology of cavernous malformations, in Awad IA, Barrow DL (eds): Cavernous Malformations. Park Ridge, Illinois: AANS, 1993: 13-23

16. Jooma R, Yeh HS, Privitera MD, Gartner M: Lesionectomy versus electrophysiologically guided resection for temporal lobe tumors manifesting with complex partial seizures. J Neurosurg 83:231-236, 1995
17. Kondziolka D, Lunsford LD, Flickinger JC, Kestle JR: Reduction of hemorrhage risk after stereotactic radiosurgery for cavernous malformations. J Neurosurg 83:825-831, 1995

18. Kondziolka D, Lunsford LD, Kestle JR: The natural history of cerebral cavernous malformations. J Neurosurg 83:820-824, 1995

19. Kraemer DL, Awad IA: Vascular malformations and epilepsy: Clinical considerations and basic mechanisms. Epilepsia 35 Suppl 6:30-43, 1994

20. Maraire JN, Awad IA: Intracranial cavernous malformations: Lesion behavior and management strategies. Neurosurgery 37:591-605, 1995

21. Mathiesen T, Edner G, Kihlström L: Deep and brainstem cavernomas: A consecutive 8-year series. J Neurosurg 99:3137,2003

22. New PF, Ojemann RG, Davis KR, Rosen BR, Heros R, Kjellberg RN, Adams RD, Richardson EP: MR and CT of occult vascular malformations of the brain. AJR Am J Roentgenol 147:985-993, 1986

23. Otten P, Pizzolato GP, Rilliet B, Berney J: 131 cases of cavernous angioma (cavernomas) of the CNS, discovered by retrospective analysis of 24535 autopsies (Fr). Neurochirurgie 35:82-83, 128-131, 1989

24. Pozzati E, Giangaspero F, Marliani F, Acciarri N: Occult cerebrovascular malformations after irradiation. Neurosurgery 39:677-684, 1996

25. Raychaudhuri R, Batjer HH, Awad IA: Intracranial cavernous angioma: A practical review of clinical and biological aspects. Surg Neurol 63:319-328, 2005

26. Robinson JR, Awad IA, Little JR: Natural history of the cavernous angioma. J Neurosurg 75:709-714, 1991

27. Shih YH, Pan DH: Management of supratentorial cavernous malformations: Craniotomy versus gamma knife radiosurgery. Clin Neurol Neurosurg 107:108-112, 2005

28. Siegel AM, Roberts DW, Harbaugh RE, Williamson PD: Pure lesionectomy versus tailored epilepsy surgery in treatment of cavernous malformations presenting with epilepsy. Neurosurg Rev 23:80-83, 2000

29. Stefan H, Hammen T: Cavernous haemangiomas, epilepsy and treatment strategies. Acta Neurol Scand 110:393-397, 2004

30. Steinberg GK, Chang SD, Gewirtz RJ, Lopez JR: Microsurgical resection of brainstem, thalamic, and basal ganglia angiographically occult vascular malformations. Neurosurgery 46:260-271, 2000

31. Tasker JG, Hoffman NW, Kim YI, Fisher RS, Peacock WJ, Dudek FE: Electrical properties of neocortical neurons in slices from children with intractable epilepsy. J Neurophysiol 75:931-939, 1996

32. Tomlinson FH, Houser OW, Scheithauer BW, Sundt TM Jr, Okazaki H, Parisi JE: Angiographically occult vascular malformations: A correlative study of features on magnetic resonance imaging and histological examination. Neurosurgery 34:792-800, 1994

33. Tsien C, Souhami L, Sadikot A, Olivier A, del CarpioO'Donovan R, Corns R, Patrocinio H, Parker W, Podgorsak E: Stereotactic radiosurgery in the management of angiographically occult vascular malformations. Int J Radiat Oncol Biol Phys 50:133-138, 2001 